\title{
Peningkatan Hasil Padi (Oryza sativa L.) dan Kadar Zink dalam Beras melalui Aplikasi Zink Sulfat Heptahidrat
}

\author{
Increasing Yield of Rice (Oryza sativa L.) and Zink Grain \\ Concentration with the Zinc Sulfate Heptahydrate Application
}

\author{
Maulana Hamam ${ }^{1 *}$, Bambang Pujiasmanto ${ }^{2}$, dan Supriyono ${ }^{2}$ \\ ${ }^{1}$ Program Studi Agronomi, Program Pascasarjana, Universitas Sebelas Maret \\ Jl. Ir. Sutami 36 A Surakarta, Jawa Tengah 57126, Indonesia \\ ${ }^{2}$ Program Studi Agroteknologi, Fakultas Pertanian, Universitas Sebelas Maret \\ Jl. Ir. Sutami 36 A, Surakarta, Jawa Tengah 57126, Indonesia
}

Diterima 31 Januari 2017/Disetujui 13 Juni 2017

\begin{abstract}
Zinc is an essential micro-nutrients for humans and plants. Zinc on humans is obtained from food, especially rice. This research studied the effect of zinc sulfate heptahydrate spraying application, the effect of zinc sulphate heptahydrate enriched urea application, and the interaction of both, on yield and rice zinc grain concentration in Ciherang varieties. The research was carried out by RCBD. The first factor was without spraying zinc sulfate, spraying $75 \mathrm{~g} \mathrm{~h} \mathrm{~h}^{-1}$ zinc sulfate heptahydrate and spraying $150 \mathrm{~g} \mathrm{ha}^{-1}$ zinc sulfate heptahydrate. The second factor was without zinc sulfate enriched urea, urea enriched by $7.5 \mathrm{~kg} \mathrm{ha}{ }^{-1}$ zinc sulfate heptahydrate, and urea enriched by $15 \mathrm{~kg} \mathrm{ha}^{-1}$ zinc sulfate heptahydrate. The parameters observed were grain yield, grain zinc concentration, and rice plant growth. Data were analyzed by analysis of variance at 5\% and DMRT test at 5\%. The results indicated that spraying $75 \mathrm{~g} \mathrm{ha}^{-1}$ zinc sulfate heptahydrate increased yield of rice up to $13 \%$, urea enriched by $7.5 \mathrm{~kg} \mathrm{ha}^{-1}$ zinc sulfate heptahydrate increased grain yield zinc concentration up to $33 \%$, Combination of spraying $75 \mathrm{~g} \mathrm{ha}^{-1}$ zinc sulfate heptahydrate and urea enriched by $7.5 \mathrm{~kg} \mathrm{ha}^{-1}$ zinc sulfate heptahydrate can't increased the yield and zinc grain concentration.
\end{abstract}

Keywords: rice, urea, zinc, zinc sulfate heptahydrate

\section{ABSTRAK}

Zink adalah unsur mikro esensial bagi manusia dan tanaman. Asupan zink pada manusia diperoleh dari makanan, terutama beras. Kekurangan zink pada tanaman mengakibatkan kadar zink dalam biji rendah dan kemampuan ekspresi genetik berkurang. Tujuan penelitian ini mempelajari penggunaan zink sulfat heptahidrat untuk meningkatkan kadar zink beras dan hasil padi Ciherang. Penelitian ini dilaksanakan di Yogyakarta pada bulan September 2015-Januari 2016, pada lahan sawah beririgasi setengah teknis. Percobaan dilakukan dengan metode RAKL faktorial. Faktor pertama adalah tanpa penyemprotan zink sulfat, penyemprotan zink sulfat heptahidrat $75 \mathrm{~g} \mathrm{ha}^{-1}$ dan penyemprotan zink sulfat heptahidrat $150 \mathrm{~g} \mathrm{ha}$ ${ }^{1}$. Faktor kedua adalah pemupukan urea tanpa zink sulfat, pemupukan urea diperkaya $7.5 \mathrm{~kg} \mathrm{ha} a^{-1}$ zink sulfat heptahidrat dan pemupukan urea diperkaya $15 \mathrm{~kg} \mathrm{ha}^{-1}$ zink sulfat heptahidrat. Parameter yang diamati adalah hasil per hektar, kosentrasi zink dalam beras, dan pertumbuhan tanaman. Data dianalisis varian taraf $5 \%$ dan DMRT taraf $5 \%$. Hasil penelitian menunjukkan, penyemprotan zink sulfat heptahidrat $75 \mathrm{~g} \mathrm{ha}^{-1}$ meningkatkan hasil padi hingga $13 \%$, pemupukan urea diperkaya $7.5 \mathrm{~kg} \mathrm{ha}^{-1}$ zink sulfat meningkatkan kadar zink dalam beras hingga 33\%. Kombinasi penyemprotan zink sulfat $75 \mathrm{~g} \mathrm{ha}^{-1}$ dan pemupukan urea diperkaya $7.5 \mathrm{~kg} \mathrm{ha}^{-1}$ zink sulfat tidak meningkatkan hasil padi dan kadar Zn dalam beras.

Kata kunci: padi, urea, zink, zink sulfat heptahidrat

\footnotetext{
* Penulis untuk korespondensi. e-mail: maulanahamamm@gmail.com
} 


\section{PENDAHULUAN}

Komoditas pangan utama penduduk Indonesia adalah beras. Peningkatan produksi dan produktivitas padi yang terjadi di Indonesia dari tahun ke tahun sejalan dengan perkembangan varietas padi unggul yang ada saat ini (Wahyuti et al., 2013). Varietas padi (Oryza sativa L.) paling populer ditanam oleh petani adalah Ciherang. Secara genetis, produktivitas padi var. Ciherang mencapai 9 ton $\mathrm{ha}^{-1}$, namun di tingkat petani hanya mencapai 5-6 ton ha ${ }^{-1}$ (Badan Pusat Statistik, 2015). Diperlukan upaya-upaya khusus untuk meningkatkan produktivitas dan kualitas padi di Indonesia.

Beras sebagai makanan pokok berfungsi sebagai penyedia nutrisi bagi manusia. Salah satu nutrisi esensial bagi manusia adalah zink. Asupan zink pada manusia tergantung pada banyaknya kadar zink pada makanan yang dikonsumsi. Hafeez et al. (2012) mengemukakan bahwa zink berperan penting dalam menjaga kesehatan sistem imun, pertumbuhan, pembentukan jaringan, kedewasaan seksual laki-laki, kinerja enzim, dan membantu tubuh dalam memerangi infeksi. Kekurangan zink pada manusia menurut Prasad (2007) dapat menyebabkan komplikasi gangguan kesehatan, pertumbuhan fisik terganggu, sistem kekebalan tubuh menurun, risiko infeksi penyakit meningkat, terjadi kerusakan DNA dan dapat menjadi pemicu pertumbuhan kanker.

Dosis zink harian yang optimum bagi manusia minimal 34.7-43.4 ppm, padahal kandungan zink pada beras varietas unggul baru (VUB) adalah 23.9 ppm, bahkan kadar zink dalam beras Ciherang baru mencapai 16.5 ppm (Yustisia et $a l ., 2013)$. Di sisi lain, zink juga merupakan salah-satu unsur mikro esensial bagi tanaman yang dibutuhkan dalam jumlah yang tepat agar mendapatkan pertumbuhan yang normal dan hasil yang optimal dan kualias gizi hasil tanaman tersebut (Sadeghzadeh, 2013). Zink terlibat dalam sejumlah proses fisiologis dan metabolisme tanaman seperti aktivasi enzim, sintesis protein, metabolisme karbohidrat, lipid, auksin, asam nukleat, ekspresi gen, dan perkembangan alat reproduksi (pembentukan serbuk sari) (Hafeez et al., 2012).

Anomali iklim global yang saat ini kerap terjadi berdampak terhadap sulitnya memprediksi intensitas banjir yang melanda pertanaman padi di lahan rawan banjir, baik durasi terendamnya tanaman maupun ketinggian permukaan airnya (Yullianida et al., 2014). Lahan padi yang tergenang beresiko kekurangan ketersediaan zink yang dapat berakibat pada penurunan hasil padi (Muthukumararaja et al., 2012). Padi sawah sangat berisiko kekurangan zink, karena pada tanah tergenang, kadar zink akan menurun. Penggenangan akan mengakibatkan peningkatan $\mathrm{pH}$ tanah sehingga menyebabkan pembentukan zink sulfide $(\mathrm{ZnS})$, dan peningkatan kadar ion divalent ferrous $\left(\mathrm{Fe}^{2+}\right)$ dan mangan $\left(\mathrm{Mn}^{2+}\right)$. Aktifitas ion-ion tersebut sangat mempengaruhi penyerapan zink oleh akar (Alloway, 2008).

Kadar zink dalam tanah merupakan faktor penentu utama ketersediaan zink dalam tanaman, kemudian faktor genetis, dan pupuk (Wissuwa et al., 2009). Tanaman yang secara genetik memiliki kemampuan baik dalam menghasilkan zink, membutuhkan zink lebih banyak. Jika kebutuhan tersebut tidak terpenuhi maka tanaman tidak dapat mengekspresikan potensi genetik secara maksimal (Alloway, 2008). Penggunaan pupuk organik dapat meningkatkan mikroorganisme tanah yang dapat membantu meningkatkan ketersediaan unsur mikro tanah seperti zink, besi, tembaga, dan lain-lain. Namun khususnya zink, peningkatan aktivitas mikroba pemecah zink saja tidak cukup. Ketersediaan zink pada lahan sawah secara umum berada pada taraf $50 \%$ dibawah standar kebutuhan zink bagi tanaman, yaitu $1.5 \mathrm{ppm}$, sedangkan mikrobia tanah hanya mampu meningkatkan kadar zink sebesar $0.008 \%$ (Mishra, 2014). Pengembalian jerami ke lahan sawah juga tidak dapat meningkatkan ketersediaan zink, karena bahan organik mengikat zink dalam senyawa komplek menjadi senyawa yang tidak tersedia bagi tanaman (Wissuwa et al., 2009). Oleh karena itu pemupukan zink masih merupakan cara yang terbaik untuk meningkatkan serapan zink ke tanaman, sekalipun pada sistem pertanian ramah lingkungan.

Cara meningkatkan serapan zink pada tanaman dapat dilakukan dengan cara genetis dan pemupukan. Cara genetis seperti pemuliaan tanaman saat ini terkendala oleh keterbatasan plasma nutfah dan ketersediaan zink di lahan. Cara lain adalah dengan pemupukan ke daun (foliar spraying) atau dengan pemberian pupuk ke dalam tanah bersamaan dengan pemberian pupuk urea (ZEU/Zink-Enriches Urea) (Shivay et al., 2008). Pupuk zink paling populer digunakan di dunia adalah zink sulfat. Zink sulfat tersedia dalam dua jenis yaitu kristal monohidrat $\left(\mathrm{ZnSO}_{4} \mathrm{H}_{2} \mathrm{O}\right)$ dengan kadar zink 36\% dan kristal heptahidrat $\left(\mathrm{ZnSO}_{4} 7 \mathrm{H}_{2} \mathrm{O}\right)$ dengan kadar zink 22\%. Dosis pupuk zink sulfat berkisar antara 4.5$34 \mathrm{~kg} \mathrm{ha}^{-1}$ (Alloway, 2008).

Saat ini sangat dibutuhkan teknik-teknik budidaya yang dapat digunakan untuk mempertahankan, bahkan meningkatkan serapan zink untuk pertumbuhan dan kadar dalam biji. Penelitian ini bertujuan untuk mencari dosis penyemprotan zink sulphat, dosis zink sulphat yang ditambahkan dalam pupuk urea dan mengetahui pengaruh kombinasi kedua perlakuan tersebut yang dapat meningkatkan kadar zink dalam beras dan hasil padi var. Ciherang.

\section{BAHAN DAN METODE}

Penelitian dilakukan di lahan sawah berpengairan teknis, dengan tekstur tanah lempung berpasir, di ketinggian 27 mdpl, tepatnya di Desa Wijirejo, Kec. Pandak, Kab. Bantul, Propinsi DI Yogyakarta $\left(7^{0}, 902\right.$ BT - $110^{0}, 303$ LS), pada bulan September 2015-Januari 2016, menggunakan padi Varietas Ciherang. Analisis tanah dan analisis kadar zink pada beras dilakukan di Laboratorium. Penelitian menggunakan metode percobaan dengan RAKL faktorial $2 \times 3$. Faktor I adalah penyemprotan zink sulfat heptahidrat (ZSH) yang terdiri atas 3 aras yaitu tanpa penyemprotan ZSH, penyemprotan ZSH $75 \mathrm{~g} \mathrm{ha}^{-1}$, ZSH $150 \mathrm{~g} \mathrm{ha}^{-1}$. Faktor II adalah penambahan ZSH dalam pemupukan urea yang terdiri atas 3 aras yaitu: urea tanpa $\mathrm{ZSH}$, urea diperkaya 7.5 $\mathrm{kg} \mathrm{ha}^{-1} \mathrm{ZSH}$, dan urea diperkaya $15 \mathrm{~kg} \mathrm{ha}^{-1} \mathrm{ZSH}$. Sampel 
tanah sebelum perlakuan di analisis kadar N, P, K, Ca, Zink, Fe dalam tanah tersebut.

Benih dijemur selama 2 jam, kemudian dicuci untuk menghilangkan kotoran dan benih hampa, kemudian direndam selama 24 jam, selanjutnya diperam selama 36 jam sampai muncul radikula, kemudian disebar di persemaian. Pemeliharaan persemaian meliputi pengairan, pemupukan dan pengendalian hama penyakit. Benih ditanam dua tanaman per lubang tanam pada umur 20 hari setelah sebar. Tanah sawah diolah menggunakan traktor pada 15 hari sebelum tanam, kemudian digenangi dan dibuat petak percobaan sesuai lay out dengan ukuran $1.2 \mathrm{~m} \times 1.1 \mathrm{~m}$. Jarak tanam yang digunakan adala $22 \mathrm{~cm}$ x $22 \mathrm{~cm}$, sehingga jumlah rumpun/petak adalah 20.

Pengairan lahan dilakukan secara periodik satu kali dalam satu minggu. Air dari saluran irigasi dialirkan ke dalam plot melalui kanal-kanal di samping plot, hingga menggenang. Kanal-kanal ini berfungsi menjaga agar tidak terjadi pencampuran pengairan antar plot. Pengairan dihentikan saat tahap masak susu tanaman padi selesai. Penyiangan dilakukan pada umur 40 hari setelah tanam (HST), sebelum pemupukan kedua. Penyiangan secara manual dilakukan dengan menghilangkan gulma yang ada di dalam plot-plot penelitian. Pengelolaan hama penyakit dilakukan secara periodik. Pupuk yang digunakan sesuai rekomendasi lokal adalah urea $250 \mathrm{~kg} \mathrm{ha}^{-1}$, TSP $100 \mathrm{~kg} \mathrm{ha}^{-1}$, $\mathrm{KCl} 75 \mathrm{~kg} \mathrm{ha}^{-1}$. Pemupukan pertama dilakukan $15 \mathrm{HST}$. Pemupukan kedua diberikan pada 45 HST.

Zink sulfat heptahidrat disemprotkan ke tanaman dalam tiga tahap yaitu pada 15 HST 25\% dosis, 45 HST 30\% dosis, dan 75 HST $45 \%$ dosis. Rekomendasi pemupukan urea di lokasi penelitian adalah sebanyak $250 \mathrm{~kg} \mathrm{ha}^{-1}$ diberikan dalam dua tahap yaitu 15 HST $150 \mathrm{~kg} \mathrm{ha}^{-1}$, dan 45 HST $100 \mathrm{~kg} \mathrm{ha}^{-1}$. Penambahan ZSH pada pemupukan urea tahap pertama adalah $60 \%$ dari dosis perlakuan, $40 \%$ ditambahkan saat pemupukan urea tahap kedua. ZSH dicampur dengan pupuk urea, kemudian diaplikasikan dengan cara ditaburkan ke tanah di samping tanaman.

Pemanenan dilakukan saat biji padi sudah 100\% masak, yaitu saat berumur 100 HST. Pemanenan dilakukan dengan cara mencabut tanaman sampel pada setiap plot. Kemudian tanaman sampel diamati tinggi tanaman, jumlah anakan, jumlah malai, jumlah biji per malai, dan persentase biji hampa. Setelah pengamatan selesai, biji di rontokkan kemudian dijemur hingga kadar air 14\% untuk hasil padi. Biji padi hasil sampel ini kemudian dianalisis kandungan zink dalam beras di laboratorium.

Variabel utama pengamatan adalah kadar zink dalam beras pada setiap plot berdasarkan hasil laboratorium dan hasil per hektar. Variabel pendukung yang diamati adalah analisis tanah sebelum dan sesudah perlakuan, meliputi kadar nitrogen, fosfor, kalium, kalsium, seng, besi dan pertumbuhan tanaman meliputi jumlah biji per malai, dan bobot 1,000 biji. Analisis statistik menggunakan analisis ragam (analysis of variance) 5\%, terhadap data hasil pengamatan kadar zink dalam gabah, hasil gabah dan pertumbuhan tanaman. Perbandingan hasil rerata dilakukan uji lebih lanjut dengan DMRT (Duncan Multiple Range Test) 5\%. Data hasil pengamatan tentang kadar N, P, K, Ca,
Zn, dan Fe di lahan sebelum penelitian di analisis secara deskriptif.

\section{HASIL DAN PEMBAHASAN}

\section{Ketersediaan Zink di Lahan Penelitian}

Tabel 1 menunjukkan bahwa kadar zink dalam tanah penelitian berada pada taraf sangat rendah $(0.092$ ppm), kadar fosfor sangat tinggi (75 me $\left.\mathrm{g}^{-100}\right)$, kadar besi pada taraf sedang $(50.82 \mathrm{ppm})$, nitrogen pada taraf sedang $(0.32 \%)$, serta kadar kalium dan kalsium berada pada kategori sangat rendah $(0.63 \%$ dan $0.95 \%)$. Mousavi et al. (2012) dan Alloway (2008) melaporkan bahwa serapan zink dapat menurun karena peningkatan kadar fosfor, besi, dan nitrogen. Alloway (2008) mengemukakan bahwa kadar ideal zink dalam tanah adalah 50 ppm, dan ketersediaannya bagi tanaman sangat tergantung oleh keberadaan unsur hara lain seperti N, P, K, Ca, dan Fe.

\section{Peningkatan Kadar Zink dalam Beras}

Kadar zink dalam beras meningkat secara signifikan dengan adanya aplikasi pemupukan urea diperkaya zink sulfat heptahidrat. Gambar 1 menjelaskan bahwa kadar zink dalam beras pada perlakuan urea tanpa diperkaya ZSH (kontrol) hanya sebesar 14.5 ppm, sedangkan kadar zink dalam beras pada perlakuan urea diperkaya ZSH 7.5 $\mathrm{kg} \mathrm{ha}^{-1}$ dan $15 \mathrm{~kg} \mathrm{ha}^{-1}$ secara berurutan meningkat menjadi 19.4 ppm dan 19.6 ppm. Hasil ini sesuai dengan yang laporkan oleh Shivay et al. (2008), bahwa aplikasi zink yang ditambahkan dalam pupuk urea cukup efektif dalam meningkatkan kadar zink dalam beras. Yadav et al. (2011) juga menjelaskan secara lebih spesifik dengan menyebutkan bahwa aplikasi urea diperkaya $1.5 \%$ zink sulfat paling baik untuk meningkatkan hasil gabah dan serapan zink dalam beras.

Secara genetis, kadar zink pada beras varietas ciherang adalah 16.5 ppm (Yustisia et al., 2013). Peningkatan 33\% dan $35 \%$ kadar zink dalam beras pada penelitian ini antara lain disebabkan karena, zink diserap secara terus menerus oleh padi dalam waktu yang lebih lama, disertai mineralisasi nitrogen (Hafeez et al., 2013), sementara itu, nitrogen

Tabel 1. Hasil analisis unsur hara dalam tanah sebelum penelitian

\begin{tabular}{lcl}
\hline Unsur hara & Kadar dalam tanah & \multicolumn{1}{c}{ Harkat } \\
\hline $\mathrm{Zn}$ & $0.09 \mathrm{ppm}$ & Sangat rendah \\
$\mathrm{P}$ & $75.00\left(\mathrm{me} \mathrm{g}^{-100}\right)$ & Sangat tinggi \\
$\mathrm{N}$ & $0.32 \%$ & Sedang \\
$\mathrm{K}$ & $0.63 \%$ & Sangat rendah \\
$\mathrm{Ca}$ & $0.95 \%$ & Sangat rendah \\
$\mathrm{Fe}$ & $50.82 \mathrm{ppm}$ & Sedang \\
\hline
\end{tabular}

Sumber: Analisis Laboratorium, berdasarkan Sulaeman et al., (2005) 


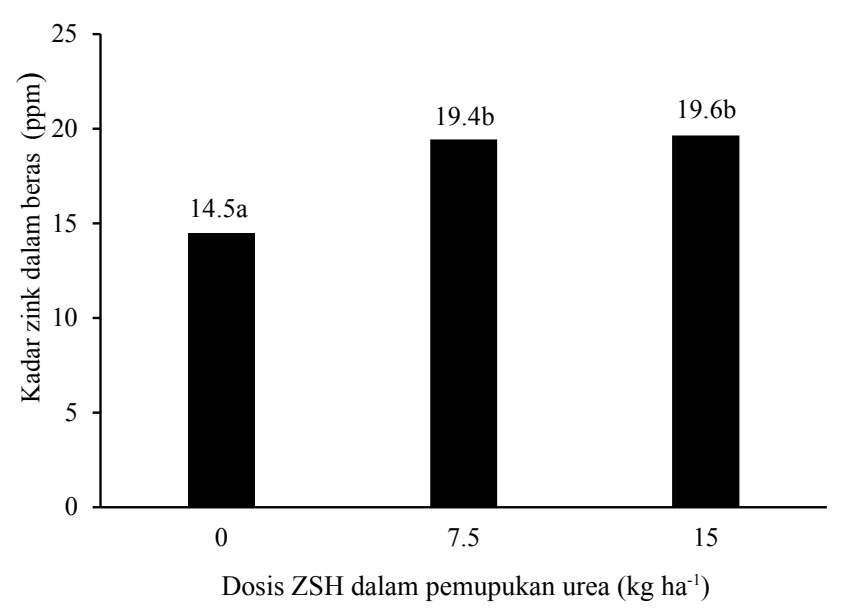

Keterangan: Kolom dengan huruf yang sama berarti tidak beda nyata berdasarkan Duncan 5\%

Gambar 1. Kadar zink dalam beras (ppm) akibat penambahan ZSH dalam pemupukan urea

dalam kombinasi zink dan nitrogen mampu meningkatkan pertumbuhan tanaman dan mengubah $\mathrm{pH}$ tanah di sekitar akar (Alloway, 2008). Zink yang terakumulasi kedalam biji berasal dari serapan akar, bukan remobilisasi dari daun (Jiang et al., 2007), karena lebih dari setengah kadar zink dalam gabah yang diperoleh saat panen adalah berasal dari zink pada masa pertumbuhan vegetatif, bukan serta-merta didapat saat masa generatif ( $\mathrm{Wu}$ et al., 2010). Selain itu, zink yang diaplikasikan dalam tanah juga sangat efektif dalam mencukupi kebutuhan untuk metabolisme tanaman, tidak sekedar menambah kadar zink dalam biji (Boocuay et al., 2013). Proses transportasi zink dari akar hingga terakumulasi dalam biji telah dijelaskan oleh Yoneyama et al. (2015) yang menjelaskan bahwa zink pada tanaman padi ditranportasikan melalui akar, kemudian dikirim ke tunas melalui sistem xylem yang berupa ion bebas dan floem dalam bentuk Zn-NA kompleks, kemudian ditranportasikan lagi ke biji melalui floem. Cakmak (2008) melaporkan bahwa peningkatan kadar zink dapat dilakukan dengan pemupukan zink dalam tanah maupun daun dalam dosis yang lebih besar dari yang diperlukan tanaman untuk dapat meningkatkan penyerapan zink ke tanaman dan translokasi zink kedalam biji.

\section{Peningkatan Hasil Padi}

Penyemprotan zink sulfat heptahidrat dapat meningkatkan hasil padi per hektar secara signifikan. Gambar 2 menjelaskan bahwa hasil padi per hektar tanpa penyemprotan ZSH (kontrol) hanya sebanyak 6.97 ton ha $^{-1}$, sedangkan hasil padi per hektar dengan aplikasi penyemprotan $75 \mathrm{~g} \mathrm{ha}^{-1}$ dan $150 \mathrm{~g} \mathrm{ha}^{-1}$ meningkat secara berturut-turut menjadi 7.88 ton $\mathrm{ha}^{-1}$ dan 7.80 ton ha-1. Peningkatan hasil padi per hektar hingga $13 \%$ ini sesuai dengan Mustafa et al. (2011) yang melaporkan bahwa hasil padi meningkat secara signifikan dengan adanya penyemprotan zink sulphat. Sarwar (2011) dan Keram et al. (2012) mengemukakan bahwa pemupukan zink dapat meningkatkan hasil padi karena zink berperan penting sebagai co-factor dari berbagai enzim yang berbeda di banyak jalur biokimia yang berperan dalam metabolisme karbohidrat, baik dalam fotosintesis dan konversi gula ke pati, metabolisme protein,metabolisme auksin, pembentukan serbuk sari, pemeliharaan kemampuan membran biologis, biosintesis IAA, inisiasi primordial dan ketahanan terhadap infeksi oleh patogen tertentu. Penelitian Tariq et al. (2014) juga melaporkan bahwa penyempotan zink sulfat pada jagung menghasilkan biji lebih banyak dibandingan dengan pemupukan zink sulfat dalam tanah.

Bobot 1,000 biji berkorelasi cukup erat dengan hasil padi dalam penelitian ini $(\mathrm{r}=0.56)$. Penyemprotan $\mathrm{ZSH}$ berpengaruh signifikan terhadap berat 1,000 biji. Tabel 2 menjelaskan bahwa bobot 1,000 biji padi tanpa penyemprotan ZSH (kontrol) hanya seberat $25.18 \mathrm{~g}$, sedangkan bobot 1,000 biji padi dengan aplikasi penyemprotan $75 \mathrm{~g} \mathrm{ha}^{-1}$ dan $150 \mathrm{~g} \mathrm{ha}^{-1}$ meningkat secara berturut-turut menjadi $29.25 \mathrm{~g}(16.16 \%)$ dan $31.07 \mathrm{~g}(19.42 \%)$. Hasil ini sama dengan yang dikemukakan oleh Mustafa et al. (2011) yang melaporkan bahwa bobot 1,000 biji padi meningkat secara signifikan dengan adanya penyemprotan zink karena dapat meningkatkan pembentukan atau penurunan pemanfaatan karbohidrat dalam jaringan tanaman sehingga dapat meningkatkan kualitas biji, mengurangi jumlah biji tidak sempurna, mengurangi biji berwarna kusam, dan mengurangi jumlah biji tidak normal.

\section{Pengaruh Kombinasi perlakuan Zink Sulfat Heptahidrat}

Kombinasi perlakuan penyemprotan Zink sulfat heptahidrat dan penambahan ZSH dalam pemupukan urea tidak berpengaruh signifikan terhadap kadar zink dalam beras dan hasil padi. Dampak signifikan dari kombinasi perlakuan tersebut terjadi pada jumlah biji per malai. Hasil penelitian yang ditampilkan pada Gambar 3 menunjukkan bahwa kombinasi penambahan $7.5 \mathrm{~kg} \mathrm{ha}^{-1} \mathrm{ZSH}$ dalam pemupukan urea dan penyemprotan ZSH $75 \mathrm{~g} \mathrm{ha}^{-1}$ menghasilkan jumlah biji terbanyak yaitu 150 biji per malai, atau 22\% lebih banyak

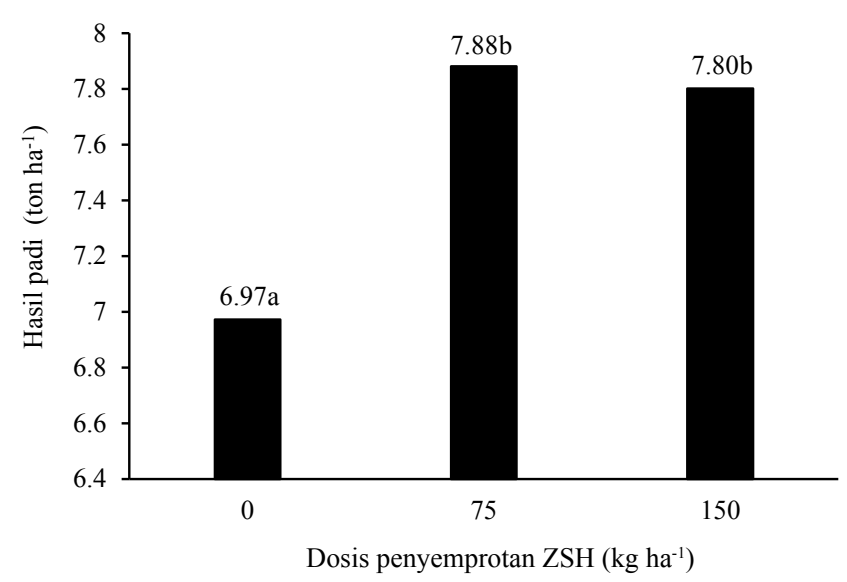

Keterangan: Kolom dengan huruf yang sama berarti tidak beda nyata berdasarkan Duncan 5\%

Gambar 2. Hasil padi (ton ha-1) akibat penyemprotan ZSH 
Tabel 2. Pengaruh penyemprotan ZSH dan Penambahan zink sulfat heptahidrat dalam pemupukan urea terhadap bobot 100 biji

\begin{tabular}{lc}
\hline Perlakuan & Bobot 100 biji $(\mathrm{g})$ \\
\hline Tanpa penyemprotan ZSH & $25.183 \mathrm{a}$ \\
Penyemprotan ZSH $75 \mathrm{~g} \mathrm{ha}^{-1}$ & $29.254 \mathrm{~b}$ \\
Penyemprotan ZSH $150 \mathrm{~g} \mathrm{ha}^{-1}$ & $31.073 \mathrm{~b}$ \\
Tanpa pemupukan urea yang diperkaya ZSH & $29.880 \mathrm{a}$ \\
Pemupukan urea yang diperkaya $7.5 \mathrm{~kg} \mathrm{ha}^{-1} \mathrm{ZSH}$ & $27.919 \mathrm{a}$ \\
Pemupukan urea yang diperkaya $15 \mathrm{~kg} \mathrm{ha}^{-1} \mathrm{ZSH}$ & $27.712 \mathrm{a}$ \\
\hline
\end{tabular}

Keterangan: Angka yang diikuti huruf yang sama pada kolom yang sama menunjukkan hasil yang tidak berbeda nyata berdasarkan DMRT pada $\alpha=5 \%$

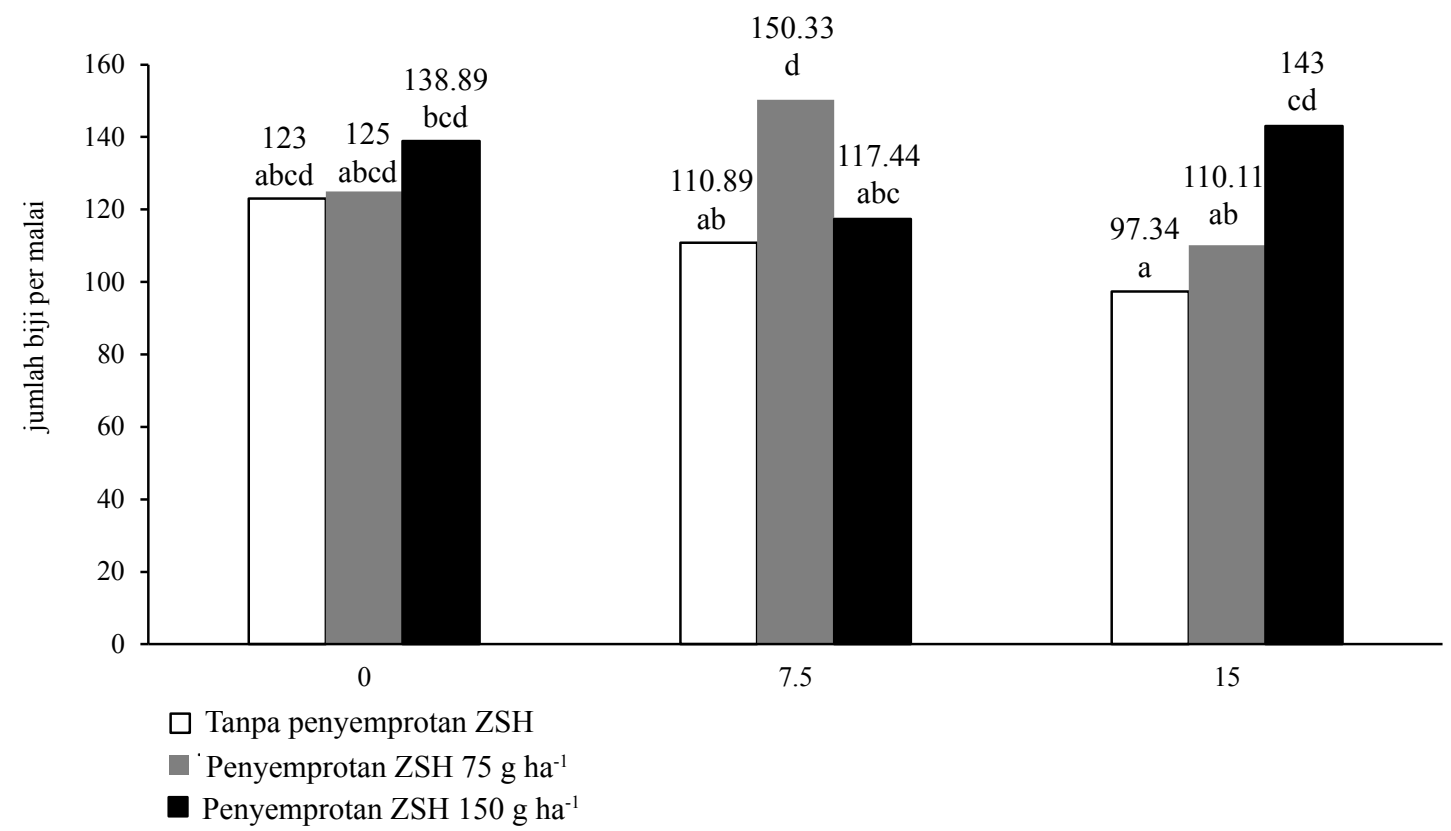

Keterangan: Kolom dengan huruf yang sama berati tidak beda nyata berdasarkan Duncan 5\%

Gambar 3. Jumlah biji per malai akibat perlakuan penyemprotan zink sulfat heptahidrat dan penambahan zink sulfat heptahidrat dalam pemupukan urea

daripada kontrol. Hasil ini sesuai dengan yang dikemukakan oleh Mustafa et al. (2011) bahwa aplikasi zink sulphat secara signifikan meningkatkan jumlah tandan biji per malai dan jumlah biji per malai. Boocuay et al. (2013) melaporkan bahwa aplikasi zink dalam tanah dapat membantu mencukupi kebutuhan zink bagi setiap tahap pertumbuhan tanaman. Alloway, (2008) yang menyataka bahwa pemupukan zink pada saat pembungaan dapat mengurangi resiko terjadinya peningkatan pembentukan asam absisat (ABA) yang dapat menyebabkan hilangnya kuncup bunga, bakal daun, dan pertumbuhan anter maupun serbuk sari yang tidak normal. Pemupukan zink sulfat tidak hanya dapat meningkatkan jumlah biji padi saja. Kurniawati et al. (1998) melaporkan bahwa aplikasi pupuk boron 3,350 ppm yang kemudian diikuti dengan zink 2,500 ppm dapat meningkatkan jumlah pentil kakao terbentuk hingga $18.3 \%$.

\section{KESIMPULAN}

Penyemprotan zink sulfat heptahidrat $75 \mathrm{~g} \mathrm{ha}^{-1}$ meningkatkan hasil padi hingga 13\%. Perlakuan pemupukan urea yang diperkaya $7.5 \mathrm{~kg} \mathrm{ha}^{-1}$ zink sulfat heptahidrat meningkatkan kadar zink dalam beras hingga $33 \%$. Kombinasi antara perlakuan penyemprotan zink sulfat heptahidrat $75 \mathrm{~g} \mathrm{ha}^{-1}$ dan pemupukan urea yang diperkaya $7.5 \mathrm{~kg} \mathrm{ha}^{-1}$ zink sulfat heptahidrat tidak meningkatkan konsentrasi zink dalam beras dan hasil padi.

\section{DAFTAR PUSTAKA}

Alloway, B.J. 2008. Zinc in Soils and Crop Nutrition. Second Edition. Belgium: International Zinc Association.

Badan Pusat Statistik. 2015. Produksi, Produktivitas, dan Luas Panen Padi, Jagung dan Kedelai di Indonesia. www.bps.go.id. [15 Januari 2016]. 
Boonchuay, P., I. Cakmak, B. Rerkasem, C. Prom-U-Thai. 2013. Effect of different foliar zinc application at different growth stages on seed zinc concentration and its impact on seedling vigor in rice. J. Soil Sci. Plant Nutr. 59:180-188.

Cakmak, I. 2008. Enrichment of cereal grains with zinc: agronomic or genetic biofortification. J. Plant Soil. 302:1-17.

Hafeez, R., T. Aziz, M. Farooq, A. Wakeel, Z. Rengel. 2012. Zinc nutrition in rice production systems: A review. J. Plant Soil. 361:203-226.

Jiang, W., P.C. Struik, J. Lingna, H.V. Keulen, Z. Ming, T.J. Stomph. 2007. Uptake and distribution of root applied or foliar applied $\mathrm{Zn}$ after flowering in aerobic rice. J. Ann. Appl. Biol. 150:383-391.

Keram, K.S., B.L. Sharma, S.D. Sawarkar. 2012. Impact of $\mathrm{Zn}$ application on yield, quality, nutrients uptake and soil fertility in a medium deep black soil (vertisol). Int. J. Sci. Environ. Technol. 1:563-571.

Kurniawati, A., A. Wachjar, A.T.H. Sinaga. 1998. Pengaruh pupuk Boron (B) dan Seng (Zn) terhadap layu pentil dan buah kakao (Theobroma cacao L.) yang dapat dipanen. Bul. Agron. 26:8-12.

Mishra, P. 2014. Rejuvenation of biofertilizer for sustainable agriculture and economic development. J. Sustainable Develop. 11:41-61.

Mousavi, S.R., M. Galavi, M. Rezaei. 2012. The interaction of zinc with other elements in plants: A review. Int. J. Agric. Crop Sci. 4:1881-1884.

Mustafa, G., Ehsanullah, N. Akbar, S.A. Qaisrani, A. Iqbal, Haroon, Z. Khan, K. Jabran, A.M. Chattha, R. Trethowa, T. Chattha, B. Manzoor. 2011. Effect of zinc application on growth and yield of rice (Oryza sativa L.) Int. J. Agro Vet. Med. Sci. 5: 530-535.

Muthukumararaja, T.M., M.V. Sriramachandrasekharan. 2012. Effect of zinc on yield, zinc nutrition and zinc use efficiency of lowland rice. J. Agric. Technol. 8:551-561.

Prasad, A.S. 2007. Zinc: Mechanisms of host defense. J. Nutrient. 137:1345-1349.

Sadeghzadeh, B. 2013. A review of zinc nutrition and plant breeding. J. Soil Sci. Plant Nutr. 13: 905-927.
Sarwar, M. 2011. Effects of Zinc fertilizer application on the incidence of rice stem borers (Scirpophaga species) (Lepidoptera: Pyralidae) in rice (Oryza sativa L.) crop. J. Cereals Oilseeds. 2:61-65.

Shivay, Y. S., D. Kumar, R. Prasad. 2008. Effect of zincenriched urea on productivity, zinc uptake and efficiency of an aromatic rice-wheat cropping system. J. Nutr. Cycling Agroecosyst. 81: 229-243.

Tariq, A., A.A. Shakeel, A. Mahmood, Randhawa, E. Ullah, M. Naeem, R. Qamar, U. Ashraf, M. Nadeem. 2014. Influence of zinc nutrition on growth and yield behaviour of maize (Zea mays L.) Hybrids. American J. Plant Sci. 5:2646-2654.

Wahyuti, T.B., B.S. Purwoko, A. Junaedi, Sugiyanta, B. Abdullah. 2013. Hubungan karakter daun dengan hasil padi varietas unggul. J. Agron. Indonesia 41: 181-187.

Wissuwa, M., A.M. Ismail, R.D. Graham. 2007. Rice grain zinc concentrations as affected by genotype, native soil-zinc, and zinc fertilization. J. Plant Soil 10:107114.

Wu, C.Y., L.L. Lu, X.E. Yang, Y. Feng, Y.Y. Wei, H.L. Hao, P.J. Stofella, Z.L. He. 2010. Uptake, translocation, and remobilization of zinc absorbed at different growth stages by rice genotypes of different $\mathrm{Zn}$ densities. J. Agric. Food Chem. 2010:6767-6773.

Yadav, G.S., D. Kumar, Y.S. Shivay, N. Singh. 2011. Agronomic evaluation of zinc-enriched urea formulations in scented rice (Oryza sativa). Indian. J. Agric. Sci. 81: 366-370.

Yoneyama, T., S. Ishikawa, S. Fujimaki. 2015. Route and regulation of Zinc, Cadmium, and Iron transport in rice plants (Oryza sativa L.) during vegetative growth and grain filling: Metal transporters, metal speciation, grain $\mathrm{Cd}$ reduction and $\mathrm{Zn}$ and Fe biofortification. Int. J. Mol. Sci. 16:19111-19129.

Yullianida, Suwarno, S.W. Ardie, H. Aswidinnoor. 2014. Uji cepat toleransi tanaman padi terhadap cekaman rendaman pada fase vegetatif. J. Agron. Indonesia 42:89-95.

Yustisia, Tohari, D. Shiddieq, Subowo. 2012. Pengkayaan Besi (Fe) dan Seng ( $\mathrm{Zn}$ ) dalam beras dan karakter penentu varietas padi sawah efisien pada tanah vertisol dan inseptisol. J. Agric. Sci. 2:67-75 